\title{
An Expedient Synthesis of Tacrine-Squaric Hybrids as Potent, Selective and Dual-Binding Cholinesterase Inhibitors
}

\author{
Marco A. Ceschi, ${ }^{(i *, a}$ Renan M. Pilotti, ${ }^{a}$ João P. B. Lopes, ${ }^{a}$ Henrique Dapont, ${ }^{a}$ João B. T. da Rocha, ${ }^{*, b}$ \\ Blessing A. Afolabi, ${ }^{\circledR b}$ Isabella A. Guedes ${ }^{c}$ and Laurent E. Dardenne* ${ }^{*, c}$ \\ anstituto de Química, Universidade Federal do Rio Grande do Sul, \\ Av. Bento Gonçalves, 9500, Campus do Vale, 91501-970 Porto Alegre-RS, Brazil \\ ${ }^{b}$ Laboratório de Bioquímica Toxicológica, Departamento de Bioquímica e Biologia Molecular, \\ Universidade Federal de Santa Maria, 97105-900 Santa Maria-RS, Brazil \\ 'Laboratório Nacional de Computação Científica, \\ Av. Getulio Vargas, 333, 25651-075 Petrópolis-RJ, Brazil
}

\begin{abstract}
The restoration of acetylcholine levels in the brain by inhibition of cholinesterases is currently the most successful therapeutic strategy to treat neurodegenerative disorders. In this context, tacrine has been largely investigated as a starting scaffold for the development of promising new anticholinesterases compounds for the treatment of neurodegenerative illnesses, including Alzheimer's disease. Here we present a series of compounds containing the tacrine nucleus connected with squaric moiety by a diaminoalkylene chain. The compounds were obtained through a simple and short synthetic route and showed high inhibitory activity against acetylcholinesterase (AChE) within nanomolar $\mathrm{IC}_{50}$ (half maximal inhibitory concentration). The molecular modelling study showed that these compounds act as dual-binding inhibitors of AChE, interacting with both catalytic active site (CAS) and peripheral anionic site (PAS) of the enzyme's binding cavity. The investigated compounds also demonstrated outstanding selectivity for AChE than in butyrylcholinesterase (BuChE). These results evince these compounds as promising agents for the treatment of neurodegenerative disorders and a fuller synthetic scope jointly with complementary biological evaluations are currently under investigation in our laboratory.
\end{abstract}

Keywords: tacrine, cholinesterase inhibitors, AChE, hybrids, squaric acid, molecular docking

\section{Introduction}

The majority of the noticed cognitive decline and behavioral changes in neurodegenerative disorders are postulated to be a result of the deficiencies in cholinergic pathways of the brain. ${ }^{1}$ In this context, the use of cholinesterase inhibitors (ChEIs) is a pivotal part in the management of various human dementias, including Alzheimer's disease (AD). ${ }^{2}$ Clinical studies ${ }^{3}$ show that these drugs can improve cognitive function of $\mathrm{AD}$ patients and four commercial products have been introduced into the market, namely tacrine, galantamine, rivastigmine, and donepezil. In addition, another of the five approved drugs for neurodegenerative diseases is memantine, an inhibitor of $N$-methyl-D-aspartate (NMDA) receptor, acting as a modulator of glutamatergic dysfunction. ${ }^{4}$

*e-mail: mceschi@iq.ufrgs.br; jbtrocha@yahoo.com.br; dardenne@lncc.br
Essentially, there are two cholinesterases enzymes: acetylcholinesterase (AChE) and butyrylcholinesterase (BuChE). The primary function of AChE is to hydrolyze and inactivate acetylcholine (ACh), the principal neurotransmitter of the central nervous system. ${ }^{2,3}$ Recently, several studies ${ }^{5}$ have provided a broad knowledge regarding $\mathrm{AChE}$ functions, as well as this close association with other key elements for AD pathogenesis, highlighting that this field still has great potential for drug development. In this context, many theoretical and experimental studies ${ }^{6,7}$ have been developed to find compounds with the ability to inhibit AChE.

The first ChEI utilized for the treatment of AD was tacrine (THA, Figure 1), approved by the Food and Drug Administration (FDA) in 1993. Tacrine is a reversible and non-competitive inhibitor of AChE that binds mainly by stacking interaction with $\operatorname{Trp} 84$ at the catalytic active site (CAS), at the bottom of the binding cavity. ${ }^{8}$ However, 
it has been discontinued due to its severe side effects. ${ }^{3}$ In spite of that, due to its easily synthetic structure and strong activity, tacrine has been largely investigated as a starting scaffold for the synthesis of multitarget-directed ligands (MTDLs) and as a repurposing drug candidate for Alzheimer's therapy.7 The connection of tacrine with another pharmacophore could improve the biological profile of THA and overcome some side effects. ${ }^{8}$ Moreover, it is recognized that dual binding site inhibitors are able to reach both CAS and peripheral anionic site (PAS) of cholinesterases, where the heptylene-linked bis(7)-tacrine (Figure 1) is about 1,000-fold more potent than THA. ${ }^{9}$ In this context, several examples of tacrine-based alkylenelinked hybrids have appeared in the literature. ${ }^{10}$

Squaramic acids (Figure 1) are four-membered ring monoamide derivatives of squaric acid and contains donor and acceptor hydrogen bond sites and an aromatic character that allows typical interactions of aromatic compounds such as $\pi$-stacking. ${ }^{11,12}$ Exploiting their facile synthetic approaches, compounds containing squaric acid derivatives have shown a wide scope in medicinal chemistry including kinase inhibition, potassium channel blockade, antimalarial, anticancer, among others. ${ }^{13}$ In recent times, a number of squaramide-containing small-molecule drugs have entered clinical trials. Perzinfotel, as well as memantine, is a potent NMDA receptor antagonist that has been investigated for the treatment of neurological disorders such as stroke and neuropathic pain. ${ }^{14,15}$ Likewise, an antagonist of the chemokine receptors CXCR1 and CXCR2 navarixin was brought to phase 2 clinical trials for chronic obstructive pulmonary disease (COPD) and as a combination therapy against a range of metastatic solid tumors. ${ }^{13}$ Recently, a series of tacrine-squaramide homodimers using squaramide moiety as part of the linker were obtained by Svobodova et al. ${ }^{16}$ These compounds were found to be potent inhibitors of both $\mathrm{AChE}$ and $\mathrm{BuChE}$, with $\mathrm{IC}_{50}$ (half maximal inhibitory concentration) in the micromolar to nanomolar range.

In connection with our continuous interest in the development of multitarget-directed hybrids to treat neurodegenerative disorders, ${ }^{10,17}$ here we present a series of compounds containing tacrine nucleus connected with squaric moiety by a diaminoalkylene chain. We believe that the small and highly functionalized squaramic ring enables strong binding interactions in the PAS of cholinesterases once tacrine has a strong interaction with CAS. The choice for an alkylene chain spaced connecting both nuclei permit simultaneous binding at the CAS and PAS. ${ }^{9}$ Also, the donor and acceptor hydrogen bond sites might increase the inhibitor's bioavailability as well as their permeability in biological barriers. In addition, the remarkable strategy of combining a squaric derivative with tacrine, highlighted by Svobodova et al. ${ }^{16}$ recent publication, we present here a preliminary report denoting for a fuller scope of compounds that will be published soon.

\section{Results and Discussion}

The general synthesis for the novel tacrinemonosquaramide and tacrine-squaramic acid hybrids is depicted in Scheme 1. The intermediates 9-aminoalkylamino-1,2,3,4-tetrahydroacridines (1) were prepared according to a previously reported protoco ${ }^{18}$ from 9-chloro-1,2,3,4-tetrahydroacridine, that was first prepared by the cyclization of anthranilic acid with cyclohexanone. After that, we promoted the condensation of amines $\mathbf{1}$ with diethoxysquarate (2) in ethanol giving the tacrinemonosquaramides hybrids (3a-3c) in good yields (71-80\%).
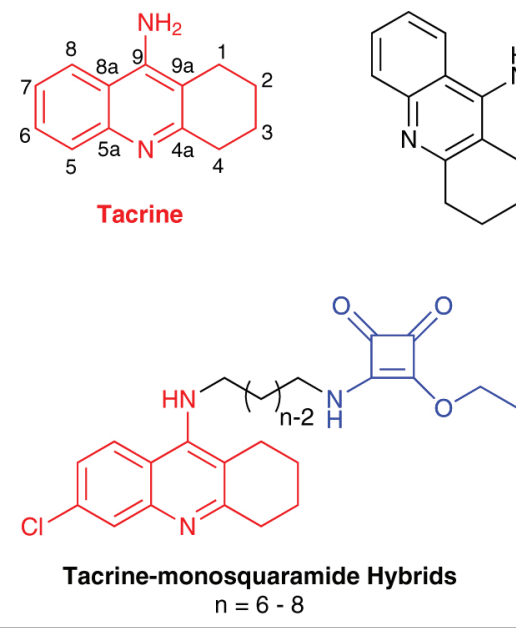

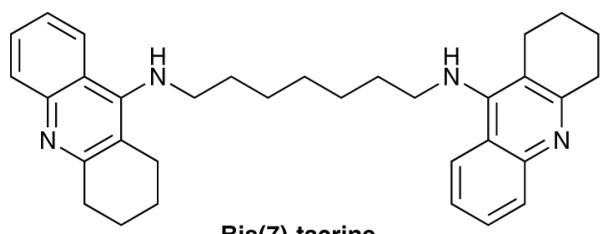

Bis(7)-tacrine

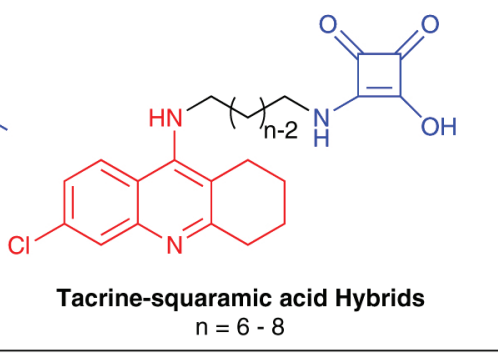

$n=6-8$

Compounds obtained in this work

Figure 1. Tacrine, bis(7)-tacrine and squaric acid derivatives. 


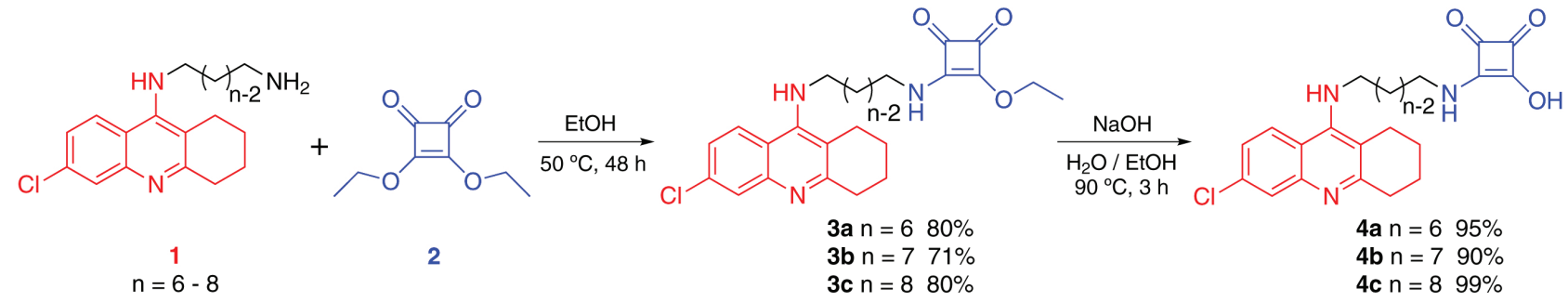

Scheme 1. Synthetic route to tacrine-based monosquaramide (3a-3c) and squaramic acid hybrids $(\mathbf{4 a - 4})$.

Table 1. Inhibitory activity against cholinesterases and the $\mathrm{IC}_{50}$ ratio of the studied compounds

\begin{tabular}{|c|c|c|c|c|c|}
\hline \multirow{2}{*}{ entry } & \multirow{2}{*}{ Compound } & \multirow{2}{*}{$\mathrm{n}$} & \multicolumn{2}{|c|}{$\mathrm{IC}_{50} / \mathrm{nM}$} & \multirow{2}{*}{$\mathrm{IC}_{50}$ ratio $\mathrm{BuChE} / \mathrm{AChE}$} \\
\hline & & & $\mathrm{AChE}$ & $\mathrm{BuChE}$ & \\
\hline 1 & $3 a$ & 6 & $0.2 \pm 0.1$ & n.a. & - \\
\hline 2 & $3 \mathbf{b}$ & 7 & $0.2 \pm 0.1$ & n.a. & - \\
\hline 3 & $3 c$ & 8 & $0.03 \pm 0.02$ & $37.4 \pm 9.37$ & 1246 \\
\hline 4 & $4 a$ & 6 & $2.5 \pm 0.9$ & n.a. & - \\
\hline 5 & $4 \mathrm{~b}$ & 7 & $1.5 \pm 0.33$ & n.a. & - \\
\hline 6 & $4 c$ & 8 & $0.2 \pm 0.05$ & $612.8 \pm 83.46$ & 3064 \\
\hline 7 & tacrine & - & $0.8 \pm 0.1$ & $6.1 \pm 1.91$ & 7.6 \\
\hline
\end{tabular}

$\mathrm{n}$ : number of methylenes in the linker; $\mathrm{IC}_{50}$ : half maximal inhibitory concentration; AChE: acetylcholinesterase; BuChE: butyrylcholinesterase; n.a.: not active at $1 \mu \mathrm{M}$ concentration.

Thereafter, alkaline hydrolysis provided tacrine-squaramic acid hybrids (4a-4c) with yields ranging 90-99\%.

In this study, all the compounds were first screened at $1 \mu \mathrm{M}$ against humans enzymes $\mathrm{AChE}$ and $\mathrm{BuChE}$ and the compounds that caused more than $50 \%$ of inhibition were further tested for $\mathrm{IC}_{50}$ determination. The results of the cholinesterase activity evaluation are shown in Table 1. All compounds were found to be highly potent and selective inhibitors of $\mathrm{AChE}$ with $\mathrm{IC}_{50}$ values in the low nanomolar concentration scale and only two (3c and $\mathbf{4 c})$ inhibit BuChE. It is noteworthy that all monosquaramides $(\mathbf{3 a - 3})$ and one of squaramic acid derivatives (4c) were significantly more potent and selective than tacrine. The compound $\mathbf{3 c}$ was the most potent inhibitor $\left(\mathrm{IC}_{50}=0.03 \mathrm{nM}\right)$ showing high affinity by the enzyme and being significantly more selective for $\mathrm{AChE}$ than $\mathrm{BuChE}$ in comparison with tacrine. Previous evidence ${ }^{19,20}$ demonstrated that selective AChE inhibitors possess a more favorable therapeutic index than nonselective inhibitors, especially in the early stages of dementia. These findings are consistent once amyloid fibrils formation is more specifically promoted by the peripheral site of $\mathrm{AChE} .^{21}$

The ensemble docking strategy adopted in this work was successfully validated with all the reference ligands docked with root mean square deviation (RMSD) $\leq 2 \AA$ in the respective protein conformation with the lowest GlideScore (Table 2). The co-crystallized ligand of the complex 1ZGC was docked with a GlideScore of $-13.4 \mathrm{kcal} \mathrm{mol}^{-1}$ and
RMSD of $1.5 \AA$ in the $1 \mathrm{Q} 84$ conformation, corresponding to a docking score slightly better than that obtained within its native conformation (GlideScore $=-12.3 \mathrm{kcal} \mathrm{mol}^{-1}$ and $\operatorname{RMSD}=1.5 \AA$ ).

Table 2. Ensemble docking of the reference ligands for the four AChE conformations and single docking against the $\mathrm{BuChE}$

\begin{tabular}{lccc}
\hline Compound & Conformation $^{\mathrm{a}}$ & $\begin{array}{c}\text { GlideScore / } \\
\left(\mathrm{kcal} \mathrm{mol}^{-1}\right)\end{array}$ & RMSD / \\
\hline $1 \mathrm{ZGC}$ & $1 \mathrm{Q} 84(\mathrm{AChE})$ & $-13.4(-12.3)^{\mathrm{b}}$ & $1.5(1.5)$ \\
$1 \mathrm{Q} 84$ & $1 \mathrm{Q} 84(\mathrm{AChE})$ & -14.8 & 1.3 \\
$2 \mathrm{CKM}$ & 2CKM $(\mathrm{AChE})$ & -12.0 & 1.1 \\
$4 \mathrm{EY7}$ & 4EY7 $(\mathrm{AChE})$ & -12.2 & 1.0 \\
$5 \mathrm{~K} 5 \mathrm{E}$ & $5 \mathrm{~K} 5 \mathrm{E}(\mathrm{BuChE})$ & -8.8 & 1.3 \\
\hline
\end{tabular}

${ }^{a}$ Conformation with the lowest GlideScore in the ensemble docking experiment; ' $\mathrm{b}$ GlideScore and RMSD against the native conformation. RMSD: root mean square deviation; AChE: acetylcholinesterase; BuChE: butyrylcholinesterase.

All evaluated compounds were predicted as low nanomolar AChE inhibitors with GlideScore values around $-13.0 \mathrm{kcal} \mathrm{mol}^{-1}$ (Table S1, Supplementary Information (SI) section). For BuChE, the compound $\mathbf{3 c}$ was predicted as the most potent inhibitor against $\mathrm{BuChE}$ at the micromolar concentration $\left(-9.1 \mathrm{kcal} \mathrm{mol}^{-1}\right)$, whereas the remaining compounds were predicted to bind into the $\mathrm{BuChE}$ binding site with GlideScores worse than $-8.0 \mathrm{kcal} \mathrm{mol}^{-1}$. These results are in consensus with the in vitro experiments 
evaluation where all compounds inhibited $\mathrm{AChE}$ in the nanomolar $\mathrm{IC}_{50}$ scale and compound $\mathbf{3 c}$ was the unique compound that inhibited $\mathrm{BuChE}$ in this potency order (Table 1, entry 3 ). The binding modes predicted for compound 3c with $\mathrm{AChE}$ and $\mathrm{BuChE}$ are illustrated in Figure 2. In the $\mathrm{AChE}$ binding site, compound $\mathbf{3 c}$ exhibited the conserved interactions experimentally observed for the 6-chlorotacrine moiety with Trp 84 and Phe $330 .{ }^{23}$ The monosquaramide moiety was predicted to interact with the PAS region, mainly through two hydrogen bonds with the main chain of the residues Phe288 and Arg289. In the BuChE binding site, the conserved $\pi$-stacking interactions and the key hydrogen bond with the His 438 main chain experimentally observed for the tacrine moiety are lost. This difference is probably due to the presence of the chlorine atom, ${ }^{10,23}$ which interacts at a specific hydrophobic pocket only present in the AChE structure at the vicinity of the $\operatorname{Trp} 84$ residue. Despite the absence of the conserved interactions, the tacrine moiety was predicted to interact at the bottom of the binding site performing T-stacking and cation- $\pi$ interactions, mainly with the key residues Trp82 and His438. Also, the amine group of the linker is hydrogen-bonded with the Ser287 main chain $(2.95 \AA)$, located at the same position of $\operatorname{Arg} 289$ in the $\mathrm{AChE}$ structure. The squaramic nucleus was predicted to interact on a hydrophobic region of the BuChE binding site without performing polar interactions, which can lead to a significant desolvation penalty of the polar atoms of the ligand, reducing the binding affinity of the compound $\mathbf{3 c}$ against the enzyme. The replacement of the nonpolar group attached at the squaramic nucleus (i.e., ethyl, compound 3c) to a deprotonated hydroxyl group (compound 4c) was detrimental for the binding affinity, indicating that favorable interactions with this hydrophobic pocket might be important to increase the affinity of the compounds against BuChE. The top-energy docking pose of $\mathbf{4} \mathbf{c}$ against the BuChE $\left(\right.$ Emodel $=-78.6 \mathrm{kcal} \mathrm{mol}^{-1}$, GlideScore $\left.=-7.9 \mathrm{kcal} \mathrm{mol}^{-1}\right)$ was found on an inverted binding mode when compared to $3 \mathbf{c}$ (Figure 3), with the squaramic moiety placed at the bottom of the binding site and the chlorotacrine moiety oriented to the entrance of the binding cavity. However, the top-2 docking pose $\left(\right.$ Emodel $=-74.1 \mathrm{kcal} \mathrm{mol}^{-1}$, GlideScore $=-6.9 \mathrm{kcal} \mathrm{mol}^{-1}$ ), in spite of predicted with less favorable Emodel and GlideScore values, consists of a more realistic binding mode, exhibiting the chlorotacrine moiety making the conserved interactions experimentally observed at the bottom of the binding site, whereas the squaramic nucleus is oriented to the entrance of the cavity performing two hydrogen bonds with the side chains of Asn289 (3.0 $)$ and Asn68 (2.8 $\AA$ ), whereas the deprotonated hydroxyl group is exposed to the solvent.
Thus, the suboptimal interaction of $\mathbf{3 c}$, mainly due to the absence of the conserved interactions observed for tacrine moiety with Trp 84 and His 438 promoted by the presence of the chlorine atom, and the possible high polar desolvation cost of burying the squaramic group without performing compensating hydrogen bonds, might explain the lowest potency of $\mathbf{3 c}$ against $\mathrm{BuChE}$, despite being a nanomolar inhibitor. On the other hand, the binding mode of compound $\mathbf{3 c}$ and its highly inhibitory activity provide useful insights to guide further molecular optimizations to develop even more potent and selective inhibitors for AChE.

\section{Conclusions}

In this work, we synthesized a series of compounds containing tacrine nucleus connected with squaric moiety by a diaminoalkylene chain, named tacrine-monosquaramide (3a-3c) and tacrine-squaramic acid (4a-4c) hybrids. The compounds were obtained through a simple and short synthetic route starting from squaric acid, anthranilic acid, and cyclohexanone. The cholinesterase inhibition study hereby reported that all hybrids are potent and selective inhibitors of the $\mathrm{AChE}$ enzyme within nanomolar $\mathrm{IC}_{50}$. Among these compounds, the tacrine-monosquaramide $3 \mathbf{c}$ was the most potent inhibitor $\left(\mathrm{IC}_{50}=0.03 \mathrm{nM}\right)$ and the unique that inhibited $\mathrm{BuChE}$ in the nanomolar concentration scale $\left(\mathrm{IC}_{50}=37.4 \mathrm{nM}\right)$. All compounds were strongly selective to AChE. The binding modes predicted by molecular modelling are consistent with the in vitro results. All compounds have GlideScore values around $-13.0 \mathrm{kcal} \mathrm{mol}^{-1}$ for $\mathrm{AChE}$ and the value obtained for compound 3c into BuChE was around $-9 \mathrm{kcal} \mathrm{mol}^{-1}$, whereas for the remaining compounds were upper than $-8.0 \mathrm{kcal} \mathrm{mol}^{-1}$, indicating a worse affinity. Furthermore, docking results showed that all compounds were able to bind at both CAS and PAS of AChE, where the squaric moiety reach the entrance of the binding cavity.

In summary, this study showed tacrine-based hybrids containing the nucleus of squaric acid derivatives acting as dual-binding inhibitors of AChE, showing a high potency and selectivity against AChE. The predicted docking binding modes provided useful insights to guide further molecular optimizations to develop even more potent and selective inhibitors for AChE. This new class of hybrids represent promising agents for the treatment of neurodegenerative disorders and further synthetic scope along with complementary biologic studies including cytotoxicity using the HepG2, Vero and C6 astroglial cell lines; the reduction of basal secretion of SB100 protein; and their ability to cross the blood-brain barrier (BBB). 


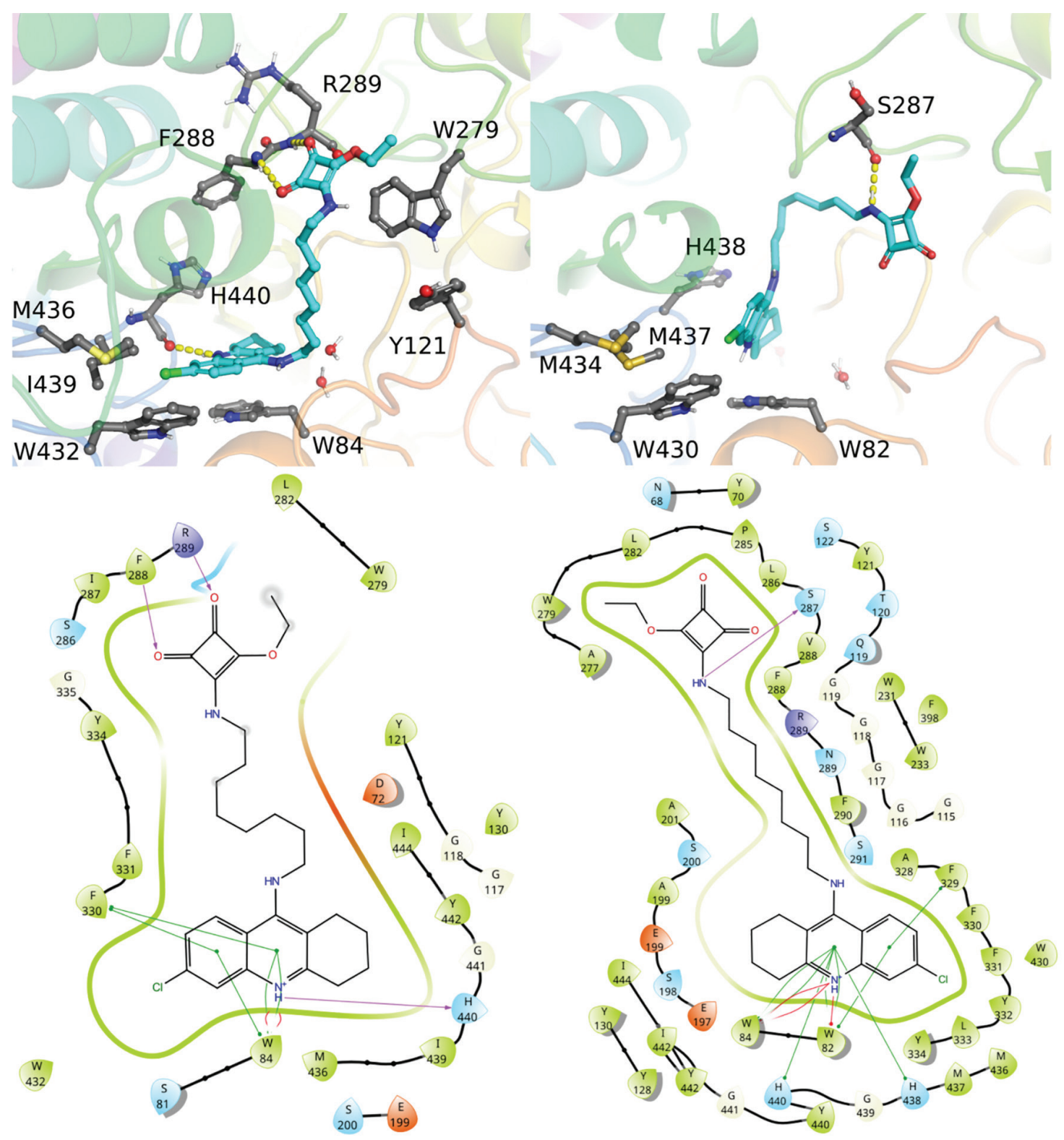

Figure 2. Docking results for compound 3c against AChE (left, PDB 1ZGC) and BuChE (right, PDB 5K5E). Hydrogen bonds are highlighted as yellow dashed lines in the 3D pictures. The 2D illustrations were generated with the Ligand Interaction Diagram tool from Maestro, ${ }^{22}$ where the hydrogen bonds, $\pi$-stacking, and cation- $\pi$ interactions are represented as pink, green and red lines.

\section{Experimental}

\section{Materials and methods}

Melting points were determined on a Büchi M-565 (Essen, Germany) melting point apparatus. Infrared (IR) spectra were recorded on a Varian 640-IR (Palo Alto, USA) spectrometer in $\mathrm{KBr}$ disks. ${ }^{1} \mathrm{H}$ and ${ }^{13} \mathrm{C}$ nuclear magnetic resonance (NMR) spectra were recorded in $\mathrm{CDCl}_{3}$ or dimethyl sulfoxide (DMSO- $d_{6}$ ) solutions on a Bruker BioSpin $400 \mathrm{MHz}$ spectrometer (BioSpin $400 \mathrm{MHz}$ spectrometer, Billerica, USA). The assignment of chemical shifts was based on standard NMR experiments $\left({ }^{1} \mathrm{H} ;{ }^{13} \mathrm{C}\right.$-APT (attached proton test); ${ }^{1} \mathrm{H},{ }^{1} \mathrm{H}-\mathrm{COSY}$ (correlation spectroscopy); ${ }^{1} \mathrm{H},{ }^{13} \mathrm{C}-\mathrm{HSQC}$ (heteronuclear single quantum correlation)). Chemical shifts $(\delta)$ are given in parts per million from the signal of tetramethylsilane $(\delta=0.00 \mathrm{ppm})$ or from the residual solvent peak $\left(\delta=2.50 \mathrm{ppm}\right.$, DMSO- $\left.d_{6}\right)$ for ${ }^{1} \mathrm{HNMR}$ and for ${ }^{13} \mathrm{C}$ NMR from the solvent signal of $\mathrm{CDCl}_{3}(\delta=77.00 \mathrm{ppm})$ or DMSO- $d_{6}$ $(\delta=39.51 \mathrm{ppm})$. Multiplicities are given as s (singlet), $\mathrm{d}$ (doublet), dd (double doublet), $\mathrm{t}$ (triplet), q (quartet), $\mathrm{m}$ (multiplet) or br (broad); coupling constants $(J)$ are given in Hz. Purification by column chromatography was carried out on silica gel 60 (70-230 mesh, Sigma-Aldrich, St. Louis, USA). Analytical thin layer chromatography 


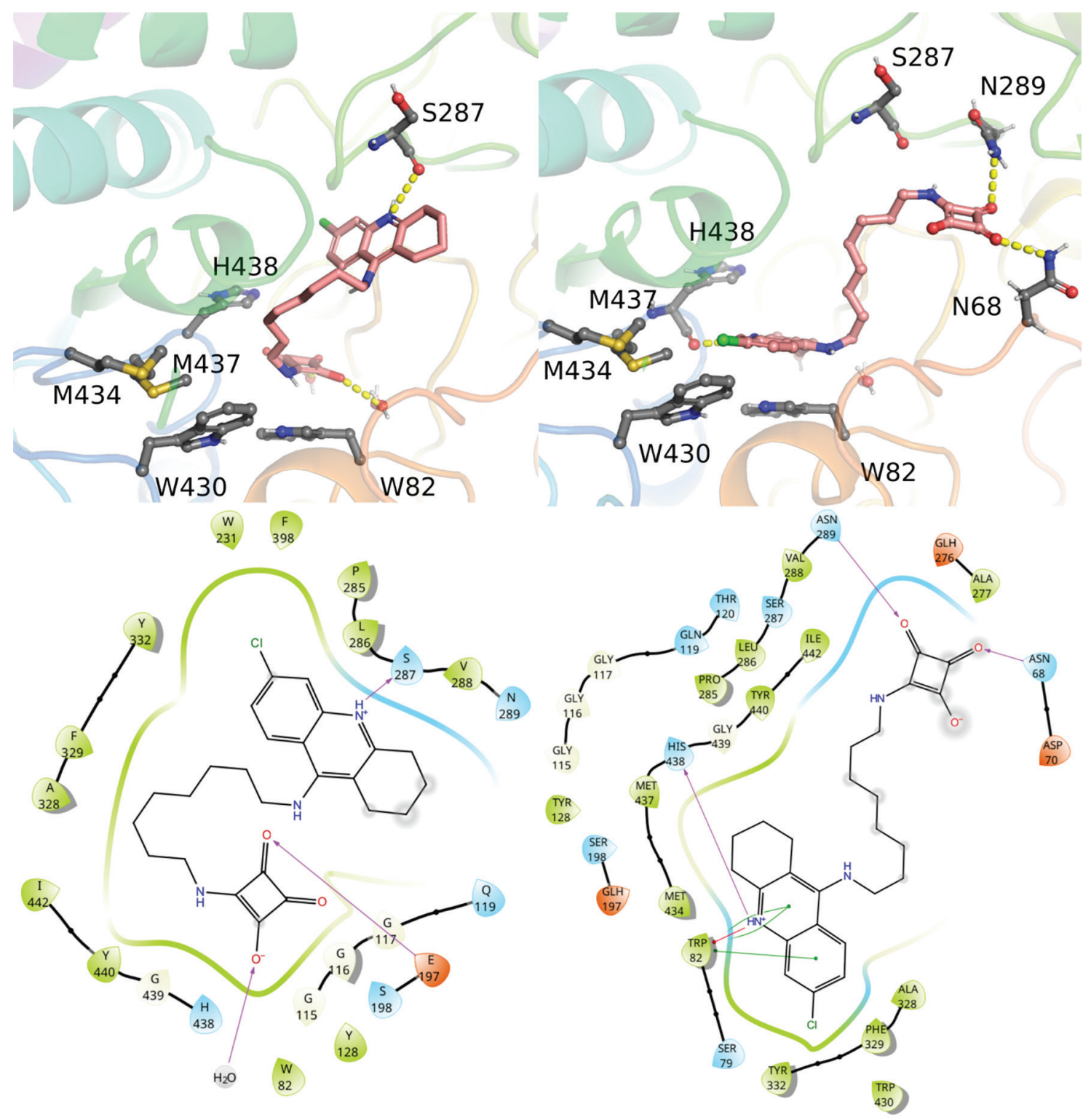

Figure 3. Docking results for compound $\mathbf{4 c}$ against BuChE (PDB code 5K5E) for the top-energy (left) and the top-2 (right) docking poses. Hydrogen bonds are highlighted as yellow dashed lines in the 3D picture. In the 2D diagrams, hydrogen bonds, $\pi$-stacking, and cation- $\pi$ interactions are represented as pink, green and red lines.

(TLC) was performed on aluminum plates with $0.2 \mathrm{~mm}$ of silica gel 60 F254 (Merck, Darmstadt, Germany). High resolution mass spectrometry with electrospray ionization (HRMS-ESI) analysis on the positive mode were carried out on a Micromass Q-Tof instrument from Waters (Manchester, UK). Samples were infused from a $100 \mathrm{~mL}$ Hamilton syringe at flow rate range from 5 to $10 \mathrm{~mL} \mathrm{~min}{ }^{-1}$, depending on the sample. The instrument settings were the following: capillary voltage, $3000 \mathrm{~V}$; cone voltage, $33 \mathrm{~V}$; extraction cone voltage, $2.5 \mathrm{~V}$; desolvation gas temperature, $100{ }^{\circ} \mathrm{C}$. Nitrogen was used as the desolvation gas. Methanol (HPLC grade, Tedia, Fairfield, OH, USA) was used as solvent for the analyzed samples and filtered prior to injection. DMSO, 5',5'-dithiobis-2-nitrobenzoic acid (DTNB), acetylthiocholine iodide, heparin, dipotassium phosphate dibasic $\left(\mathrm{K}_{2} \mathrm{HPO}_{4}\right)$ and potassium phosphate monobasic $\left(\mathrm{KH}_{2} \mathrm{PO}_{4}\right)$ were obtained from Sigma-Aldrich (St. Louis, MO, USA). Solvents were obtained from Tedia (Fairfield, $\mathrm{OH}$, USA) and Nuclear (Diadema, SP, Brazil), and reagents were purchased from Sigma-Aldrich, Acros Organics (Thermo Fisher Scientific, Waltham, Massachusetts, USA) and TCI (Tokyo, Japan). Compounds $\mathbf{1}$ and $\mathbf{2}$ were synthesized according to the previous literature procedure..$^{18,24}$

\section{Synthesis}

Preparation of 3,4-diethoxycyclobut-3-ene-1,2-dione (2) This procedure was modified from previously reported 
protocol. ${ }^{24}$ In a $25 \mathrm{~mL}$ flask, equipped with a magnetic stirrer and a reflux condenser, squaric acid $(600 \mathrm{mg}$, $5.26 \mathrm{mmol})$ was suspended in anhydrous $\mathrm{EtOH}(6 \mathrm{~mL})$ and the resulting mixture was refluxed for $3 \mathrm{~h}$ under nitrogen atmosphere. The solvent was removed under reduced pressure. The resulting white slurry was resuspended in a fresh portion of $\mathrm{EtOH}(6 \mathrm{~mL})$ and the resulting mixture was refluxed for additional $1 \mathrm{~h}$. The solvent was again removed under reduced pressure and the same procedure was repeated four times. The crude product was purified by column chromatography using a mixture of hexane:ethyl acetate (80:20, gradient) as eluent giving compound $\mathbf{2}$ as a yellowish liquid (636 mg, yield 70\%). ${ }^{1} \mathrm{H}$ NMR $(400 \mathrm{MHz}$, $\left.\mathrm{CDCl}_{3}\right) \delta 1.47(\mathrm{t}, 6 \mathrm{H}, J 7.1 \mathrm{~Hz}), 4.73(\mathrm{q}, 4 \mathrm{H}, J 7.1 \mathrm{~Hz})$; ${ }^{13} \mathrm{C}$ NMR $\left(101 \mathrm{MHz}, \mathrm{CDCl}_{3}\right) \delta 15.6,70.5,184.2,189.2$.

General procedure for the synthesis of tacrinemonosquaramide hybrids (3a-3c)

In a round bottom flask equipped with a magnetic stirrer, diethyl squarate 2 (95 mg, $0.56 \mathrm{mmol}$ ) was dissolved in $\mathrm{EtOH}(2.5 \mathrm{~mL})$ and a solution of the appropriate amine $\mathbf{1}$ $(185 \mathrm{mg}, 0.56 \mathrm{mmol})$ in $\mathrm{EtOH}(2.5 \mathrm{~mL})$ was added dropwise at $0{ }^{\circ} \mathrm{C}$. The resulting solution was stirred under nitrogen atmosphere at $50{ }^{\circ} \mathrm{C}$ for $48 \mathrm{~h}$. After that, the solvent was removed under reduced pressure till dryness and the crude product was purified by column chromatography using a mixture of $\mathrm{CH}_{2} \mathrm{Cl}_{2}: \mathrm{MeOH}$ (98:02, gradient) as eluent giving compounds $\mathbf{3 a - 3} \mathbf{c}$ in a high purity degree. All compounds were characterized by IR and NMR spectroscopy and HRMS.

3-((6-((6-Chloro-1,2,3,4-tetrahydroacridin-9-yl)amino)hexyl) amino)-4-ethoxycyclobut-3-ene-1,2-dione (3a)

Yellowish solid (80\% yield); mp 54-56 ${ }^{\circ} \mathrm{C}$; IR ( $\left.\mathrm{KBr}\right)$ $v_{\max } / \mathrm{cm}^{-1} 3357,3258,2930,2853,1803,1705,1613,1344$, $1095,945,865,813,721,685,597$; ${ }^{1} \mathrm{H}$ NMR $(400 \mathrm{MHz}$, $\left.\mathrm{CDCl}_{3}\right) \delta 1.27-1.42(\mathrm{~m}, 7 \mathrm{H}), 1.50-1.69(\mathrm{~m}, 4 \mathrm{H}), 1.74-1.90$ (m, 4H), 2.53-2.62 (m, 2H), 2.90-3.04 (m, 2H), 3.27-3.69 (m, 4H), $4.11(\mathrm{br}, 1 \mathrm{H}), 4.76$ (q, 2H, J 6.5 Hz), 5.86 (br, $1 \mathrm{H}), 6.85(\mathrm{br}, 1 \mathrm{H}), 7.18(\mathrm{dd}, 1 \mathrm{H}, J 9.1,1.9 \mathrm{~Hz}), 7.84-7.91$ (m, 2H); ${ }^{13} \mathrm{C}$ NMR $\left(101 \mathrm{MHz}, \mathrm{CDCl}_{3}\right) \delta 15.9,22.2,22.7$, 24.5, 26.0, 26.4, 29.7, 30.3, 31.4, 32.8, 44.6, 49.1, 69.7, $114.9,117.5,124.5,125.0,125.6,134.9,146.1,151.8$, 157.9, 172.5, 177.4, 182.6, 189.6; HRMS-ESI $\mathrm{m} / 2$, calcd. for $\mathrm{C}_{25} \mathrm{H}_{31} \mathrm{ClN}_{3} \mathrm{O}_{3}[\mathrm{M}]^{+}$: 456.2048, found: 456.2046 .

3-((7-((6-Chloro-1,2,3,4-tetrahydroacridin-9-yl)amino) heptyl)amino)-4-ethoxycyclobut-3-ene-1,2-dione (3b)

Yellowish solid $(71 \%)$; mp $66-68{ }^{\circ} \mathrm{C}$; IR $(\mathrm{KBr})$ $v_{\max } / \mathrm{cm}^{-1} 3348,3249,2930,2857,1803,1705,1619$, 1423, 1331, 1082, 872, 813, 767, 721, 668, 590; ${ }^{1} \mathrm{H}$ NMR $\left(400 \mathrm{MHz}, \mathrm{CDCl}_{3}\right) \delta$ 1.32-1.41 (m, 6H), $1.45(\mathrm{t}, 3 \mathrm{H}$, $J 7.0 \mathrm{~Hz}), 1.54-1.70(\mathrm{~m}, 4 \mathrm{H}), 1.86-1.96(\mathrm{~m}, 4 \mathrm{H}), 2.63-2.69$ (m, 2H), 3.00-3.08 (m, 2H), 3.41-3.66 (m, 4H), 4.16 (br, 1H), 4.77 (q, 2H, J $6.9 \mathrm{~Hz}), 5.98$ (br, 1H), 6.88 (br, 1H), 7.25-7.28 (m, $1 \mathrm{H}), 7.85-7.95(\mathrm{~m}, 2 \mathrm{H}) ;{ }^{13} \mathrm{C} \mathrm{NMR}(101 \mathrm{MHz}$, $\left.\mathrm{CDCl}_{3}\right) \delta 15.8,22.0,22.6,24.4,26.1,26.6,28.6,30.2,31.3$, 32.4, 44.6, 49.0, 69.5, 114.5, 117.2, 124.5, 125.0, 125.1, 135.1, 145.6, 152.0, 157.4, 172.5, 177.2, 182.6, 189.5; HRMS-ESI $m / z$, calcd. for $\mathrm{C}_{26} \mathrm{H}_{33} \mathrm{ClN}_{3} \mathrm{O}_{3}[\mathrm{M}]^{+}:$470.2205, found: 470.2201 .

3-((8-((6-Chloro-1,2,3,4-tetrahydroacridin-9-yl)amino)octyl) amino)-4-ethoxycyclobut-3-ene-1,2-dione (3c)

Yellowish foam (80\%); IR (KBr) $v_{\max } / \mathrm{cm}^{-1} 3370,3265$, 2924, 2852, 1803, 1711, 1613, 1429, 1337, 1082, 983, 944, 865, 813, 714, 675, 583; ${ }^{1} \mathrm{H}$ NMR (400 MHz, $\mathrm{CDCl}_{3}$ ) $\delta 1.26-1.40(\mathrm{~m}, 8 \mathrm{H}), 1.45(\mathrm{t}, 3 \mathrm{H}, J 7.1 \mathrm{~Hz}), 1.52-1.61(\mathrm{~m}$, $2 \mathrm{H}), 1.62-1.70(\mathrm{~m}, 2 \mathrm{H}), 1.89-1.96(\mathrm{~m}, 4 \mathrm{H}), 2.62-2.70(\mathrm{~m}$, $2 \mathrm{H}), 2.99-3.08(\mathrm{~m}, 2 \mathrm{H}), 3.37-3.68(\mathrm{~m}, 4 \mathrm{H}), 4.11(\mathrm{br}, 1 \mathrm{H})$, 4.77 (q, 2H, J 7.0 Hz), 5.84 (br, 1H), 6.56 (br, 1H), 7.27 (dd, 2H, J 9.1, $2.1 \mathrm{~Hz}), 7.91$ (m, 2H); ${ }^{13} \mathrm{C}$ NMR (101 MHz, $\left.\mathrm{CDCl}_{3}\right) \delta 15.9,22.1,22.7,24.4,26.1,26.6,28.9,29.0,30.4$, 31.5, 32.7, 44.8, 49.2, 69.6, 114.6, 117.4, 124.6, 125.0, 125.5, 135.0, 145.9, 152.0, 157.7, 172.5, 177.3, 182.7, 189.5; HRMS-ESI $m / z$, calcd. for $\mathrm{C}_{27} \mathrm{H}_{35} \mathrm{ClN}_{3} \mathrm{O}_{3}[\mathrm{M}]^{+}$: 484.2361, found: 484.2367 .

General procedure for the synthesis of squaramic acids $(4 a-4 c)$

Appropriate compound 3 (131 mg, $0.29 \mathrm{mmol}$ ) was suspended in a solution of $\mathrm{NaOH}(29 \mathrm{mg}, 0.72 \mathrm{mmol})$ in water $(2.5 \mathrm{~mL})$ and ethanol $(0.5 \mathrm{~mL})$. The mixture was stirred at $90{ }^{\circ} \mathrm{C}$ until TLC indicated completion of the reaction $(3 \mathrm{~h})$. The resulting solution was cooled down to room temperature and acidified with $10 \% \mathrm{HCl}$. The formed precipitate was washed with small portions of cold water and dried under reduced pressure to afford pure compounds $\mathbf{4 a - 4} \mathbf{c}$ as brown solids.

3-((6-((6-Chloro-1,2,3,4-tetrahydroacridin-9-yl)amino)hexyl) amino)-4-hydroxycyclobut-3-ene-1,2-dione (4a)

Brown solid (95\%); mp 122-124 ${ }^{\circ} \mathrm{C}$; IR (KBr) $v_{\max } / \mathrm{cm}^{-1} 3430,3278,2944,2865,1794,1697,1642$, 1559, 1427, 1350, 1240, 1080, 928, 827, 816, 740, 671, 615; ${ }^{1} \mathrm{H}$ NMR (400 MHz, DMSO- $\left.d_{6}\right) \delta 1.23-1.43(\mathrm{~m}, 4 \mathrm{H})$, $1.49(\mathrm{~m}, 2 \mathrm{H}), 1.71(\mathrm{~m}, 2 \mathrm{H}), 1.78-1.93(\mathrm{~m}, 4 \mathrm{H}), 2.56-2.70$ (m, 2H), 2.88-3.08 (m, 2H), 3.40 (q, 2H, J 12.7, $6.4 \mathrm{~Hz}$ ), 3.82 (q, 2H, J 5.6 Hz), 7.42 (br, 1H), 7.59 (dd, 1H, J 9.2, $1.9 \mathrm{~Hz}), 7.85$ (d, 1H, J $2.0 \mathrm{~Hz}), 7.88$ (br, 1H), 8.39 (d, 1H, $J 9.3 \mathrm{~Hz}$ ); ${ }^{13} \mathrm{C}$ NMR (101 MHz, DMSO- $\left.d_{6}\right) \delta 20.7,21.8$, $24.2,25.8,26.0,28.4,30.0,30.9,43.3,47.7,112.0,114.4$, 
118.4, 125.7, 128.0, 137.5, 139.1, 151.4, 155.8, 177.3, 186.3; HRMS-ESI $\mathrm{m} / z$, calcd. for $\mathrm{C}_{23} \mathrm{H}_{27} \mathrm{ClN}_{3} \mathrm{O}_{3}[\mathrm{M}]^{+}$: 428.1735, found: 428.1729 .

3-((7-((6-Chloro-1,2,3,4-tetrahydroacridin-9-yl)amino) heptyl)amino)-4-hydroxycyclobut-3-ene-1,2-dione (4b)

Brown solid (90\%); mp 113-115 ${ }^{\circ} \mathrm{C}$; IR (KBr) $v_{\max } / \mathrm{cm}^{-1} 3411,3286,2932,2850,1788,1705,1642$, $1572,1427,1358,1226,1087,928,886,824,768,727$, $685,622,539 ;{ }^{1} \mathrm{H}$ NMR (400 MHz, DMSO- $\left.d_{6}\right) \delta 1.20-1.37$ $(\mathrm{m}, 6 \mathrm{H}), 1.47(\mathrm{~m}, 2 \mathrm{H}), 1.70(\mathrm{~m}, 2 \mathrm{H}), 1.78-1.86(\mathrm{~m}, 4 \mathrm{H})$, 2.60-2.65 (m, 2H), 2.93-2.99 (m, 2H), 3.34-3.40 (m, 2H), $3.82(\mathrm{q}, 2 \mathrm{H}, J 5.8 \mathrm{~Hz}), 7.48(\mathrm{br}, 1 \mathrm{H}), 7.59(\mathrm{~d}, 1 \mathrm{H}, J 9.2 \mathrm{~Hz})$, $7.85(\mathrm{~s}, 1 \mathrm{H}), 7.90(\mathrm{br}, 1 \mathrm{H}), 8.39$ (d, 1H, J 9.3 Hz); ${ }^{13} \mathrm{C} \mathrm{NMR}$ $\left(101 \mathrm{MHz}\right.$, DMSO- $\left.d_{6}\right) \delta 20.2,21.3,23.8,25.6,26.0,27.9$, 28.0, 29.6, 30.6, 42.8, 47.2, 111.6, 113.9, 117.9, 125.2, 127.6, 137.0, 138.6, 150.9, 155.3, 178.4, 186.8, 192.2, 196.3; HRMS-ESI $m / z$, calcd. for $\mathrm{C}_{24} \mathrm{H}_{29} \mathrm{ClN}_{3} \mathrm{O}_{3}[\mathrm{M}]^{+}$: 442.1892, found: 442.1883 .

3-((8-((6-Chloro-1,2,3,4-tetrahydroacridin-9-yl)amino)octyl) amino)-4-hydroxycyclobut-3-ene-1,2-dione (4c)

Brown solid (99\%); mp $146-148{ }^{\circ} \mathrm{C}$; IR $(\mathrm{KBr})$ $v_{\max } / \mathrm{cm}^{-1} 3425,3272,2925,2856,1794,1697,1635$, 1587, 1531, 1427, 1350, 1253, 1094, 914, 879, 816, 719, 678,$615 ;{ }^{1} \mathrm{H}$ NMR $\left(400 \mathrm{MHz}\right.$, DMSO- $\left.d_{6}\right) \delta 1.11-1.37$ (m, $8 \mathrm{H}), 1.36-1.59(\mathrm{~m}, 2 \mathrm{H}), 1.60-1.77(\mathrm{~m}, 2 \mathrm{H}), 1.78-1.89(\mathrm{~m}$, $4 \mathrm{H}), 2.55-2.72(\mathrm{~m}, 2 \mathrm{H}), 2.84-3.09(\mathrm{~m}, 2 \mathrm{H}), 3.38(\mathrm{q}, 2 \mathrm{H}$, $J 6.0 \mathrm{~Hz}), 3.76-3.86$ (m, 2H), 7.48-7.74 (m, 2H), 7.81-7.99 (m, 2H), $8.41(\mathrm{dd}, 1 \mathrm{H}, J 9.1,4.0 \mathrm{~Hz}) ;{ }^{13} \mathrm{C}$ NMR $(101 \mathrm{MHz}$, DMSO- $\left.d_{6}\right) \delta 20.7,21.8,24.3,26.1,26.4,28.4,28.8,28.8$, 30.0, 31.1, 43.4, 47.7, 112.0, 114.4, 118.3, 125.6, 128.0, 137.4, 139.0, 151.4, 155.8, 178.5, 187.0, 192.0, 196.7; HRMS-ESI $\mathrm{m} / z$, calcd. for $\mathrm{C}_{25} \mathrm{H}_{31} \mathrm{ClN}_{3} \mathrm{O}_{3}[\mathrm{M}]^{+}: 456.2048$, found: 456.2030 .

\section{$\mathrm{AChE}$ and BuChE inhibition assay}

Human whole blood samples were collected in heparinized tubes and were spun at 2,000 rpm for $10 \mathrm{~min}$ to isolate the erythrocytes and plasma. The erythrocyte and plasma were gently transferred to other tubes. Erythrocytes were suspended $2 \mathrm{~mL}$ of normal saline (0.9\%) and centrifuged at 2,000 rpm for $10 \mathrm{~min}$, the washing was repeated 3 times. Before analysis of the activities of the enzymes, erythrocytes were diluted 400 times, while the plasma was diluted 40 times and stored at $-20{ }^{\circ} \mathrm{C}$ for a maximum of 5 days. The erythrocyte and plasma were obtained from male and female healthy volunteers (participants of the study) and the protocol was approved by the Human Ethics Committee of the Universidade Federal de Santa Maria (3.471.823). The erythrocyte and plasma were subsequently used for the estimations of human acetylcholinesterase and butyrylcholinesterase activities, respectively. ${ }^{25,26}$

The potential of the test compounds to inhibit the activity of $\mathrm{AChE}$ and BuChE was determined using the colorimetric method of Ellman et al. ${ }^{27}$ The system consisted of $130 \mu \mathrm{L}$ of distilled water, $20 \mu \mathrm{L} 0.1 \mathrm{M}$ potassium phosphate buffer (pH 7.4), $20 \mu \mathrm{L}$ of $10 \mathrm{mM}$ DTNB and $20 \mu \mathrm{L}$ of the sample (12-20 $\mu \mathrm{g}$ of protein from human erythrocyte or plasma). The samples were pre-incubated for $30 \mathrm{~min}\left(25^{\circ} \mathrm{C}\right)$ with $0.1 \%$ DMSO (control) or inhibitor (test compounds). Subsequently, the reaction was initiated with $10 \mu \mathrm{L}$ of $8 \mathrm{mM}$ acetylthiocholine as the substrate. The degradation of acetylthiocholine iodide was estimated for $30 \mathrm{~min}$ (30 s interval) at $415 \mathrm{~nm}$ (Spectra Max plate reader, Molecular Devices, CA, USA). The $\mathrm{IC}_{50}$ was calculated using the equation of the Dixon plot, a plot of the inverse of velocity against a varying concentration of the inhibitor and a fixed concentration of the substrate. ${ }^{28,29}$

\section{Molecular modelling}

\section{Preparation of the structures}

The three-dimensional structures of the compounds were prepared using the Maestro suite, ${ }^{22}$ and isomers, protonation states, and tautomers of the ligands were determined using LigPrep/Epik ${ }^{30,31}$ from Maestro at $\mathrm{pH} 7.0 \pm 0.4$. At neutral $\mathrm{pH}$, the hydroxyl group from the moniliformin moiety of the compounds $\mathbf{4 a}-\mathbf{4} \mathbf{c}$ was predicted to be deprotonated, being negatively charged at the oxygen atom with predicted $\mathrm{p} K_{\mathrm{a}}=1.9 \pm 2.0$. The $\mathrm{AChE}$ and $\mathrm{BuChE}$ structures were prepared with the Protein Preparation Wizard tool from Maestro. ${ }^{32}$ The protonation states of the amino acid residues were determined using PROPKA ${ }^{33}$ at $\mathrm{pH}$ 7. Interestingly, Glu199 located near the catalytic triad was predicted to be neutral due to a high $\mathrm{p} K_{\mathrm{a}}$ value (ca. 10) for all the AChE and BuChE structures. Recently, Wan et $a l .{ }^{34}$ proposed that the protonated form of Glu199 can interact with conserved water and stabilize the catalytic triad in the molecular simulations of the BuChE-tacrine complex. The optimization of the hydrogen bond network between the protein and reference ligand was performed to adjust the orientation of the hydrogen atoms, followed by energy minimization with fixed heavy atoms.

\section{Docking}

In this work, the docking experiments were performed with the molecular docking program Glide under the standard precision $(\mathrm{SP})^{35}$ mode using the ensemble and soft docking strategies to consider the protein flexibility. ${ }^{36,37}$ 
We redocked the reference ligands (i.e., the co-crystallized compounds) into their respective $\mathrm{AChE}$ and $\mathrm{BuChE}$ conformations to validate the docking protocol adopted herein. We selected four representative conformations of $\mathrm{AChE}$ for the ensemble docking strategy to consider the significant conformational changes mainly observed on the PAS. ${ }^{38,39}$ This approach consists of docking the compounds into each representative conformation of the receptor, aiming to implicitly consider large-scale protein movements. ${ }^{40,41}$ The protein conformations selected in this work were 1ZGC (Torpedo californica, solved at $2.1 \AA$ ), ${ }^{42}$ 2CKM (Torpedo californica, solved at $2.1 \AA$ ), ${ }^{43} 1 \mathrm{Q} 84$ (Mus musculus, solved at $2.4 \AA$ ), ${ }^{44}$ and 4EY7 (Homo sapiens, solved at $2.4 \AA$ ). ${ }^{45}$ All the inhibitors from the four representative conformations of $\mathrm{AChE}$ act as dual inhibitors interacting with both CAS and PAS. Four structural water molecules were explicitly considered as described in our previous work. ${ }^{17}$ For each ligand, the top-energy pose was selected according to the lowest Emodel value (i.e., the Emodel is the Glide scoring function recommended to evaluate different poses of the same ligand). Finally, the binding mode with the lowest GlideScore among the four $\mathrm{AChE}$ representative structures was selected for each compound. For BuChE, we selected the conformation complexed with the inhibitor 6QS (PDB ID 5K5E from Homo sapiens, solved at $2.8 \AA$ ), and maintained three structural water molecules as described in our previous work. ${ }^{17}$

\section{Supplementary Information}

Supplementary data $\left({ }^{1} \mathrm{H}\right.$ and ${ }^{13} \mathrm{C}$ NMR spectra and docking results) are available free of charge at http://jbcs.sbq.org.br as PDF file.

\section{Acknowledgments}

We would like to thank the following Brazilian agencies for financial support and fellowships: CNPq, FAPERGS, CAPES, PROPESQ-UFRGS, LNCC.

\section{Author Contributions}

Marco A. Ceschi was responsible for the conceptualization, data curation, formal analysis, funding acquisition, investigation, methodology, project administration, resources, supervision, writing original draft, review and editing; Renan M. Pilotti for the data curation, formal analysis, investigation and methodology; João P. B. Lopes for the data curation, visualization, writing original draft, review and editing; Henrique Dapont for the data curation and methodology; João B. T. da Rocha for the data curation, formal analysis, funding acquisition, investigation, methodology, resources and supervision; Blessing A. Afolabi for the data curation, formal analysis, investigation, methodology, validation and writing original draft; Isabella A. Guedes for the conceptualization, data curation, formal analysis, investigation, software, writing original draft, review and editing; Laurent E. Dardenne for the conceptualization, data curation, funding acquisition, investigation, software, supervision and writing original draft.

\section{References}

1. Shah, A. A.; Dar, T. A.; Dar, P. A.; Ganie, S. A.; Kamal, M. A.; Curr. Drug Metab. 2017, 18, 96.

2. Sharma, K.; Mol. Med. Rep. 2019, 20, 1479.

3. Tezel, G.; Timur, S. S.; Bozkurt, I.; Türkoğlu, Ö. F.; Eroğlu, I.; Nemutlu, E.; Öner, L.; Eroğlu, H.; Chem. Pharm. Bull. 2019, 67, 1030.

4. Alam, S.; Lingenfelter, K. S.; Bender, A. M.; Lindsley, C. W.; ACS Chem. Neurosci. 2017, 8, 1823.

5. Wang, H.; Zhang, H.; ACS Chem. Neurosci. 2019, 10, 852.

6. Oliveira, A. S.; Meier, L.; Zapp, E.; Brondani, D.; Brighente, I. M. C.; Sá, M. M.; J. Braz. Chem. Soc. 2019, 30, 1045.

7. Santos, M. A.; Chand, K.; Chaves, S.; Future Med. Chem. 2016, 8, 2113; Wang, N.; Qiu, P.; Cui, W.; Yan, X.; Zhang, B.; He, S.; Curr. Med. Chem. 2019, 26, 5684; Mishra, P.; Kumar, A.; Panda, G.; Bioorg. Med. Chem. 2019, 27, 895; Sameem, B.; Saeedi, M.; Mahdavi, M.; Shafiee, A.; Eur. J. Med. Chem. 2017, 128, 332; Milelli, A.; de Simone, A.; Ticchi, N.; Chen, H. H.; Betari, N.; Andrisano, V.; Tumiatti, V.; Curr. Med. Chem. 2017, 24, 3522.

8. Girek, M.; Szymański, P.; Chem. Pap. 2019, 73, 269.

9. Pang, Y. P.; Quiram, P.; Jelacic, T.; Hong, F.; Brimijoin, S.; J. Biol. Chem. 1996, 271, 23646.

10. Roldán-Peña, J. M.; Eur. J. Med. Chem. 2019, 181, 111550; Pan, T.; Xie, S.; Zhou, Y.; Hu, J.; Luo, H.; Li, X.; Huang, L.; Bioorg. Med. Chem. Lett. 2019, 29, 2150; Lopes, J. P. B.; Silva, L.; Franarin, G. C.; Ceschi, M. A.; Lüdtke, D. S.; Dantas, R. F.; de Salles, C. M. C.; Silva-Jr., F. P.; Senger, M. R.; Guedes, I. A.; Dardenne, L. E.; Bioorg. Med. Chem. 2018, 26, 5566; Lopes, J. P. B.; da Costa, J. S.; Ceschi, M. A.; Gonçalves, C. A. S.; Konrath, E. L.; Karl, A. L. M.; Guedes, I. A.; Dardenne, L. E.; J. Braz. Chem. Soc. 2017, 28, 2218; Ceschi, M. A.; da Costa, J. S.; Lopes, J. P. B.; Câmara, V. S.; Campo, L. F.; Borges, A. C. A.; Gonçalves, C. A. S.; de Souza, D. F.; Konrath, E. L.; Karl, A. L. M.; Guedes, I. A.; Dardenne, L. E.; Eur. J. Med. Chem. 2016, $121,758$.

11. Storer, R. I.; Aciro, C.; Jones, L. H.; Chem. Soc. Rev., 2011, 40, 2330. 
12. Prohens, R.; Portell, A.; Font-Bardia, M.; Bauzá, A.; Frontera, A.; Cryst. Growth Des. 2014, 14, 2578.

13. Marchetti, L. A.; Kumawat, L. K.; Mao, N.; Stephens, J. C.; Elmes, R. B. P.; Chem 2019, 5, 1398.

14. Kinney, W. A.; Abou-Gharbia, M.; Garrison, D. T.; Schmid, J.; Kowal, D. M.; Bramlett, D. R.; Miller, T. L.; Tasse, R. P.; Zaleska, M. M.; Moyer, J. A.; J. Med. Chem. 1998, 41, 236.

15. Wu, L. J.; Zhuo, M.; Neurotherapeutics 2009, 6, 693.

16. Svobodova, B.; Mezeiova, E.; Hepnarova, V.; Hrabinova, M.; Muckova, L.; Kobrlova, T.; Jun, D.; Soukup, O.; Jimeno, M. L.; Marco-Contelles, J.; Korabecny, J.; Biomolecules 2019, 9 , 379.

17. Lopes, J. P. B.; Silva, L.; Ceschi, M. A.; Lüdtke, D. S.; Zimmer, A. R.; Ruaro, T. C.; Dantas, R. F.; de Salles, C. M. C.; SilvaJr., F. P.; Senger, M. R.; Barbosa, G.; Lima, L. M.; Guedes, I. A.; Dardenne, L. E.; Med. Chem. Commun. 2019, 10, 2089; Lopes, J. P. B.; Câmara, V. S.; Russowsky, D.; Nogara, P. A.; da Rocha, J. B. T.; Santos, F. S.; Rodembusch, F. S.; Ceschi, M. A.; J. Mol. Liq. 2019, 287, 110983; da Costa, J. S.; Lopes, J. P. B.; Russowsky, D.; Petzhold, C. L.; Borges, A. C. A.; Ceschi, M. A.; Konrath, E.; Batassini, C.; Lunardi, P. S.; Gonçalves, C. A. S.; Eur. J. Med. Chem. 2013, 62, 556.

18. Hu, M. K.; Wu, L. J.; Hsiao, G.; Yen, M. H.; J. Med. Chem. 2002, 45, 2277; Huang, Z.; Luo, W.; Li, Y.; Huang, S.; Tan, J.; Ou, T.; Li, D.; Gu, L.; Bioorg. Med. Chem. 2011, 19, 763.

19. Liston, D. R.; Nielsen, J. A.; Villalobos, A.; Chapin, D.; Jones, S. B.; Hubbard, S. T.; Shalaby, I. A.; Ramirez, A.; Nason, D.; White, W. F.; Eur. J. Pharmacol. 2004, 486, 9.

20. Saxena, M.; Ragini, D.; Curr. Top. Med. Chem. 2019, 19, 264.

21. Inestrosa, N. C.; Alvarez, A.; Perez, C. A.; Moreno, R. D.; Vicente, M.; Linker, C.; Casanueva, O. I.; Soto, C.; Garrido, J.; Neuron 1996, 16, 881.

22. Maestro (Small-Molecule Drug Discovery Suite 2018-4); Schrödinger, LLC, New York, NY, USA, 2018.

23. Camps, P.; Formosa, X.; Galdeano, C.; Gómez, T.; MuñozTorrero, D.; Ramírez, L.; Viayna, E.; Gómez, E.; Isambert, N.; Lavilla, R.; Badia, A.; Clos, M. V.; Bartolini, M.; Mancini, F.; Andrisano, V.; Bidon-Chanal, M.; Huertas, O.; Dafni, T.; Luque, F. J.; Chem.-Biol. Interact. 2010, 187, 411; Savini, L.; Gaeta, A.; Fattorusso, C.; Catalanotti, B.; Campiani, G.; Chiasserini, L.; Pellerano, C.; Novellino, E.; McKissic, D.; Saxena, A.; J. Med. Chem. 2003, 46, 1.

24. Mejuch, T.; Garivet, G.; Hofer, W.; Kaiser, N.; Fansa, E. K.; Ehrt, C.; Koch, O.; Baumann, M.; Ziegler, S.; Wittinghofer, A.; Waldmann, H.; Angew. Chem., Int. Ed. 2017, 56, 6181.

25. Worek, F.; Mast, U.; Kiderlen, D.; Diepold, C.; Eyer, P.; Clin. Chim. Acta 1999, 288, 73 .
26. Bjerrum, P. J.; J. Membr. Biol. 1979, 48, 43.

27. Ellman, G. L.; Courtney, K. D.; Andres, V.; Featherstone, R. M.; Biochem. Pharmacol. 1961, 7, 88.

28. Dixon, M.; Biochem. J. 1953, 55, 170.

29. Punekar, N. S.; Enzymes: Catalysis, Kinetics and Mechanisms, $1^{\text {st }}$ ed.; Springer Nature: Singapore, 2018.

30. Greenwood, J. R.; Calkins, D.; Sullivan, A. P.; Shelley, J. C.; J. Comput.-Aided Mol. Des. 2010, 24, 591.

31. Shelley, J. C.; Cholleti, A.; Frye, L. L.; Greenwood, J. R.; Timlin, M. R.; Uchimaya, M.; J. Comput.-Aided Mol. Des. 2007, 21, 681.

32. Sastry, G. M.; Adzhigirey, M.; Day, T.; Annabhimoju, R.; Sherman, W.; J. Comput.-Aided Mol. Des. 2013, 27, 221.

33. Olsson, M. H. M.; Søndergaard, C. R.; Rostkowski, M.; Jensen, J. H.; J. Chem. Theory Comput. 2011, 7, 525.

34. Wan, X.; Yao, Y.; Fang, L.; Liu, J.; Phys. Chem. Chem. Phys. 2018, 20, 14938.

35. Friesner, R. A.; Banks, J. L.; Murphy, R. B.; Halgren, T. A.; Klicic, J. J.; Mainz, D. T.; Repasky, M. P.; Knoll, E. H.; Shelley, M.; Perry, J. K.; Shaw, D. E.; Francis, P.; Shenkin, P. S.; J. Med. Chem. 2004, 47, 1739.

36. Ferrari, A. M.; Wei, B. Q.; Costantino, L.; Shoichet, B. K.; J. Med. Chem. 2004, 47, 5076 .

37. Guedes, I. A.; Pereira, F. S. S.; Dardenne, L. E.; Front. Pharmacol. 2018, 9, DOI 10.3389/fphar.2018.01089.

38. Bourne, Y.; Taylor, P.; Radić, Z.; Marchot, P.; EMBO J. 2003, 22,1 .

39. Johnson, G.; Moore, S. W.; Curr. Pharm. Des. 2006, 12, 217.

40. Craig, I. R.; Essex, J. W.; Spiegel, K.; J. Chem. Inf. Model. 2010, 50, 511 .

41. Guedes, I. A.; de Magalhães, C. S.; Dardenne, L. E.; Biophys. Rev. 2014, 6, 75.

42. Haviv, H.; Wong, D. M.; Greenblatt, H. M.; Carlier, P. R.; Pang, Y.-P.; Silman, I.; Sussman, J. L.; J. Am. Chem. Soc. 2005, 127, 11029.

43. Rydberg, E. H.; Brumshtein, B.; Greenblatt, H. M.; Wong, D. M.; Shaya, D.; Williams, L. D.; Carlier, P. R.; Pang, Y.-P.; Silman, I.; Sussman, J. L.; J. Med. Chem. 2006, 49, 5491.

44. Bourne, Y.; Kolb, H. C.; Radić, Z.; Sharpless, K. B.; Taylor, P.; Marchot, P.; Proc. Natl. Acad. Sci. U. S. A. 2004, 101, 1449.

45. Cheung, J.; Rudolph, M. J.; Burshteyn, F.; Cassidy, M. S.; Gary, E. N.; Love, J.; Franklin, M.; Height, J. J.; J. Med. Chem. 2012, 55,10282 .

Submitted: December 11, 2019

Published online: February 4, 2020 